\title{
Modification of $\mathrm{Mg}_{2} \mathrm{Si}$ Phase Morphology in Mg-4Si Alloy by $\mathrm{Sb}$ and Nd Additions
}

\author{
Hao Dong, Siming Xiang, Jie Lv, Yu Wang, Lu Li, and Wenbin Yu
}

\author{
(Submitted December 4, 2019; Accepted: 14 April 2020; published online June 22, 2020)
}

\begin{abstract}
We reported the effects of compound modification with $\mathrm{Nd}$ and $\mathrm{Sb}$ on the microstructure evolution and mechanical properties of $\mathrm{Mg}-4 \mathrm{Si}$ alloys. The characterization results showed that adding $1.0 \mathrm{wt} \% \mathrm{Sb}$ and 1.0 wt.\% Nd to the alloy can effectively change the morphology of $\mathrm{Mg}_{2} \mathrm{Si}$ particles. The primary $\mathrm{Mg}_{2} \mathrm{Si}$ particles changed from coarse dendrites to regular polygons, and the average particle size decreased from 78.3 to $6.5 \mu \mathrm{m}$. Meanwhile, the Chinese eutectic $\mathrm{Mg}_{2} \mathrm{Si}$ became small short fiber. The experimental results showed that the $\mathrm{Nd}_{4} \mathrm{Sb}_{3}$ phase could be formed after adding $1.0 \mathrm{wt} . \% \mathrm{Sb}$ and $1.0 \mathrm{wt} . \% \mathrm{Nd}$ to the alloy. The $\mathrm{Nd}_{4} \mathrm{Sb}_{3}$ phase could act as the heterogeneous nucleation core of $\mathrm{Mg}_{2} \mathrm{Si}$ phase, which increased the nucleation rate of $\mathrm{Mg}_{2} \mathrm{Si}$ and improved the morphology of $\mathrm{Mg}_{2} \mathrm{Si}$ particles. The mechanical properties test found that the tensile properties and Brinell hardness of the alloy were improved with Sb and Nd alloyed. After adding $1.0 \mathrm{wt} \% \mathrm{Sb}$ and $1.0 \mathrm{wt} \% \mathrm{Nd}$ to the alloy, the ultimate tensile strength increased from 113 to $184 \mathrm{MPa}$, the elongation increased from 2.23 to $4.61 \%$, and the Brinell hardness increased from 65.45 to 87.32 HB.
\end{abstract}

Keywords compound modification, magnesium alloy, mechanical property, $\mathrm{Mg}_{2} \mathrm{Si}$ phase, microstructure

\section{Introduction}

Lightweight magnesium alloys have broad applications in various fields including electronic, aerospace (Ref 1,2), and automation because of their high specific strength, high stiffness, relatively low density, good electrical conductivity, and excellent machinability (Ref 3,4). However, one of the disadvantages of magnesium alloys is that the high-temperature mechanical properties of this material are somewhat poor, and this greatly limits broader industrial applications (Ref 5,6).

Recent studies have reported methods to improve the heatresistance problem of magnesium alloys such as microalloying (Ref 7), deformation strengthening (Ref 8), and second phase strengthening (Ref 9). Apparently, introducing $\mathrm{Mg}_{2} \mathrm{Si}$ particles into the alloy was the most widely valuable because they are convenient and do not require complicated equipment. Furthermore, the $\mathrm{Mg}_{2} \mathrm{Si}$ phase has some excellent characteristics such as low density $\left(1.88 \mathrm{~g} / \mathrm{cm}^{3}\right)$, high melting point $\left(1087^{\circ} \mathrm{C}\right.$ ), high hardness (HV 460), high elastic modulus

Hao Dong, Siming Xiang, Jie Lv, Yu Wang, Lu Li, and Wenbin Yu, School of Materials and Energy, Southwest University, Chongqing 400715, China. Contact e-mails: 2994274741@qq.com,2472271338@qq.com, lvjie.swu@foxmail.com, peientiandao1000@163.com, lilu.swu@gmail.com, and ywb2747@126.com.
$(120 \mathrm{GPa})$, high elastic modulus $(120 \mathrm{GPa})$,and low thermal expansion coefficient $\left(7.5 \times 10^{-6} \mathrm{~K}^{-1}\right)(\operatorname{Ref} 10)$; the $\mathrm{Mg}_{2} \mathrm{Si}$ phase can be stably present at high temperatures and enhance the mechanical properties of the material. Thus, the $\mathrm{Mg}_{2} \mathrm{Si}$ phase is an ideal reinforcement phase for magnesium alloys.

However, many rough dendritic primary $\mathrm{Mg}_{2} \mathrm{Si}$ and Chinese eutectic $\mathrm{Mg}_{2} \mathrm{Si}$ are produced during the solidification of $\mathrm{Mg}-\mathrm{Si}$ alloy throughout the magnesium matrix. These features negatively affect the physical properties of magnesium alloys. In view of this, optimizing the morphology and structure of $\mathrm{Mg}_{2} \mathrm{Si}$ particles is necessary to improve the alloy performance.

There have been many studies demonstrating that the morphology of $\mathrm{Mg}_{2} \mathrm{Si}$ can be modified upon adding different modifiers. Previous studies have indicated that coarse dendritic primary $\mathrm{Mg}_{2} \mathrm{Si}$ particles were changed to regular polygons after adding $\mathrm{Sb}(\operatorname{Ref} 11,12), \mathrm{Nd}(\operatorname{Ref} 13,14), \mathrm{Ba}(\operatorname{Ref} 15)$, or P (Ref $10,16)$ to $\mathrm{Mg}$-Si alloys: The modification mechanism of these elements can be concluded as the formation of a heterogeneous nucleation core of the $\mathrm{Mg}_{2}$ Si phase. In addition, the $\mathrm{Y}$ (Ref 17, 18 ), $\mathrm{KBF}_{4}$ (Ref 19), and Bi (Ref 20) can also modify the coarse dendritic primary $\mathrm{Mg}_{2} \mathrm{Si}$ because they inhibit the growth of $\mathrm{Mg}_{2} \mathrm{Si}$ phase. Furthermore, the combination of two modifiers such as $\mathrm{Ba}-\mathrm{Sb}(\operatorname{Ref} 21), \mathrm{Sr}-\mathrm{Sb}(\operatorname{Ref} 22)$, and $\mathrm{Ca}-\mathrm{Sb}(\operatorname{Ref} 23)$ can alert the coarse dendritic primary $\mathrm{Mg}_{2} \mathrm{Si}$ as well. However, the size of most modification $\mathrm{Mg}_{2} \mathrm{Si}$ particles is larger than $20 \mu \mathrm{m}$, and thus, we need more effective modifiers to further refine the primary $\mathrm{Mg}_{2} \mathrm{Si}$ particles.

Previous studies have found that $\mathrm{Sb}$ transformed coarse dendritic primary $\mathrm{Mg}_{2} \mathrm{Si}$ into regular polygonal particles by increasing the number of heterogeneous nucleation sites (Ref 11). $\mathrm{Nd}$ is also an effective modifier for $\mathrm{Mg}_{2} \mathrm{Si}$ phase. Therefore, $\mathrm{Sb}$ and $\mathrm{Nd}$ would have synergistic modification effects. Thus, $\mathrm{Nd}$ and $\mathrm{Sb}$ were added to the $\mathrm{Mg}-4 \mathrm{Si}$ alloys to see the modification effect, and the objective of this work is to find an effective compound modifier and to evaluate the effect of $\mathrm{Nd}-\mathrm{Sb}$ addition on the microstructure of $\mathrm{Mg}-4 \mathrm{Si}$ alloys, as well as to explore the mechanism of $\mathrm{Nd}$ and $\mathrm{Sb}$ compound modification. 


\section{Experimental Procedures}

First, Mg ingot (> 99.9 wt.\%) and Si ingot (> 99.8 wt.\%) should be available for the preparation of Mg-4Si alloy. $1100 \mathrm{~g}$ pure $\mathrm{Mg}$ ingots were melted to $700{ }^{\circ} \mathrm{C}$, and $40 \mathrm{~g}$ fine silicon particles were added to the metal solution after the pure magnesium is melted. And $\mathrm{Mg}$ ingot was added more due to $\mathrm{Mg}$ burned easily. A small amount of covering agent was added to the surface of the molten metal during the smelting process to protect the molten metal. This was held at $700{ }^{\circ} \mathrm{C}$ for $20 \mathrm{~min}$ and stirred evenly after slag removal. The molten magnesium solution can be poured into a cast iron mold preheated at $250{ }^{\circ} \mathrm{C}$. This is the basis of subsequent experiments.

A previous study showed that the best modification effect was achieved after adding $1.0 \mathrm{wt} . \% \mathrm{Sb}$ to the $\mathrm{Mg}$-based alloy when adding a single modification element $\mathrm{Sb}$ (Ref 21). In this case, the only variable in the experiment was the difference in $\mathrm{Nd}$ content. The $1.0 \mathrm{wt} \% \mathrm{Sb}$ was added to the re-melted $\mathrm{Mg}$ 4Si alloys, and different amounts of $\mathrm{Mg}-30 \mathrm{Nd}$ alloy were added to the re-melted $\mathrm{Mg}-4 \mathrm{Si}$ alloys. The molten metal was kept at $700{ }^{\circ} \mathrm{C}$ for $20 \mathrm{~min}$. After stirring, the molten metal was poured into a cast iron mold preheated at $250{ }^{\circ} \mathrm{C}$ to obtain the samples: This produced bars $20 \mathrm{~mm}$ in diameter. Table 1 shows the designed ratios of the $\mathrm{Nd}$ and $\mathrm{Sb}$ contents of the prepared ingots.

All metallographic samples in this experiment were taken from the same position of ingot. The samples were finely ground with different meshes of sandpaper, polished with a diamond spray polish, and then etched with $0.1 \%$ acetic acid. First of all, the phase constituent of the experimental $\mathrm{Mg}-4 \mathrm{Si}$ alloy was determined by XRD (Shimadzu XRD-7000) using $\mathrm{Cu} \mathrm{K} \alpha$ radiation in step mode from $20^{\circ}$ to $80^{\circ}$ with a scanning speed of $2^{\circ} \mathrm{min}^{-1}$ and an acquisition step of $0.02^{\circ}(2 \theta)$. After that, OLYMPUS-PMG3 optical microscope (OM) was used to observe the microstructure of the samples. Finally, AxioVision software was used to calculate the average size and density of $\mathrm{Mg}_{2} \mathrm{Si}$ particles. The calculation process is as follows ( $\left.\operatorname{Ref} 24\right)$ :

Mean size $=\frac{1}{m} \sum_{j=1}^{m}\left(\frac{1}{n} \sum_{i=1}^{n} L_{i}\right)_{j}$

Mean density $=\frac{1}{m} \sum_{j=1}^{m}\left(\frac{1}{n} \sum_{i=1}^{n} D_{i}\right)_{j}$

where $L_{\mathrm{i}}$ was the size of a single $\mathrm{Mg}_{2} \mathrm{Si}$ particle and $D_{i}$ is the density of $\mathrm{Mg}_{2} \mathrm{Si}$ particles, respectively. Term $n$ was the amount of $\mathrm{Mg}_{2} \mathrm{Si}$ particles counted in this area at $71,300 \mu \mathrm{m}^{2}$, and $m$ was the number of the measurement areas. A JSM-6610 scanning electron microscope (SEM) was used to analyze the microscopic appearance and element composition of the second phase. Nanoscale second phase particles were observed and analyzed by transmission electron microscopy (TEM), and the

Table 1 Alloy number and nominal Nd/Sb contents

\begin{tabular}{llllll}
\hline Alloy number & $\mathbf{1}$ & $\mathbf{2}$ & $\mathbf{3}$ & $\mathbf{4}$ & $\mathbf{5}$ \\
\hline Sb content, wt.\% & 0 & 1.0 & 1.0 & 1.0 & 1.0 \\
Nd content, wt.\% & 0 & 0 & 0.5 & 1.0 & 2.0 \\
\hline
\end{tabular}

samples were prepared by focusing particle beams. Titan G2 $60-300$ model was used for TEM observation at $300 \mathrm{kV}$. The elemental composition of the second phase was obtained by mapping analysis, and the crystal structure of the second phase was determined by selected area electron diffraction.

Tensile test bars were prepared in accordance with the ASTMB557 M-02a standard, and the gauge length was set to $30 \mathrm{~mm}$, and the cross section diameter was $6 \mathrm{~mm}$. This tensile test was performed by use of a CMT5504 universal testing machine controlled by computer in the constant crosshead speed of $1 \mathrm{~mm} / \mathrm{min}$, and each sample was tested five times at room temperature. The fracture surface was observed by SEM, and the average ultimate tensile strength (UTS) and elongation were calculated. The hardness of samples was tested by use of a Brinell hardness tester (HBE-D3000A) under $2450 \mathrm{~N}$ load, with $15 \mathrm{~s}$ residence time and $\Phi 2.5$ indenter. The present values in this paper are the average value of five random different positions.

\section{Experiment Results and Discussion}

\subsection{Phase Analysis}

Figure 1 shows the XRD examination results of Alloy 1 to 5 , and it is clear that $\mathrm{Mg}_{2} \mathrm{Si}$ phase and $\mathrm{Mg}$ phase were observed in the $\mathrm{Mg}-4 \mathrm{Si}$ alloy, indicating that $\mathrm{Mg}_{2} \mathrm{Si}$ phase was formed during the solidification.

\subsection{Microstructure Evolution}

Figure 2 shows the microstructure of $\mathrm{Mg}-4 \mathrm{Si}$ alloys under different $\mathrm{Nd}$ and $\mathrm{Sb}$ addition values. The microstructure of unmodified Mg-4Si alloy (Fig. 2a) is composed of white $\alpha-\mathrm{Mg}$ matrix, and Chinese eutectic $\mathrm{Mg}_{2} \mathrm{Si}$ and coarse black primary $\mathrm{Mg}_{2} \mathrm{Si}$ dendrites had a size of about $78 \mu \mathrm{m}$. According to the binary phase diagram of magnesium-silicon, dendritic primary $\mathrm{Mg}_{2} \mathrm{Si}$ is first precipitated during the solidification process and then precipitates Chinese character eutectic $\mathrm{Mg}_{2} \mathrm{Si}$.

By adding $1.0 \mathrm{wt} . \% \mathrm{Sb}$ to the $\mathrm{Mg}-4 \mathrm{Si}$ alloy, the morphology of primary $\mathrm{Mg}_{2} \mathrm{Si}$ particles can significantly change from coarse dendrites to regular polygons (Fig. 2b) and the size reduced to about $20 \mu \mathrm{m}$, while the amount of Chinese eutectic $\mathrm{Mg}_{2} \mathrm{Si}$ was

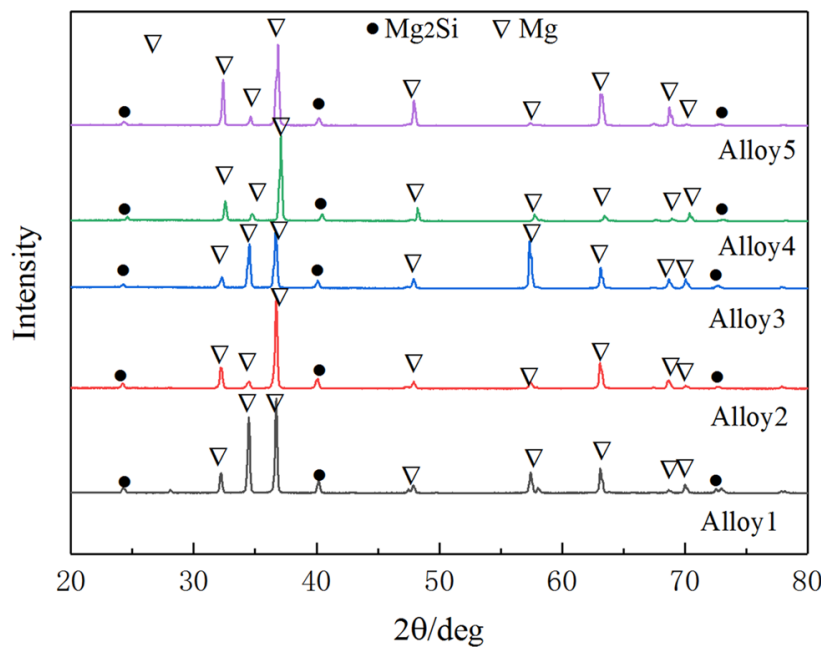

Fig. 1 XRD patterns of alloy 1, alloy 2, alloy 3, alloy 4, alloy 5 

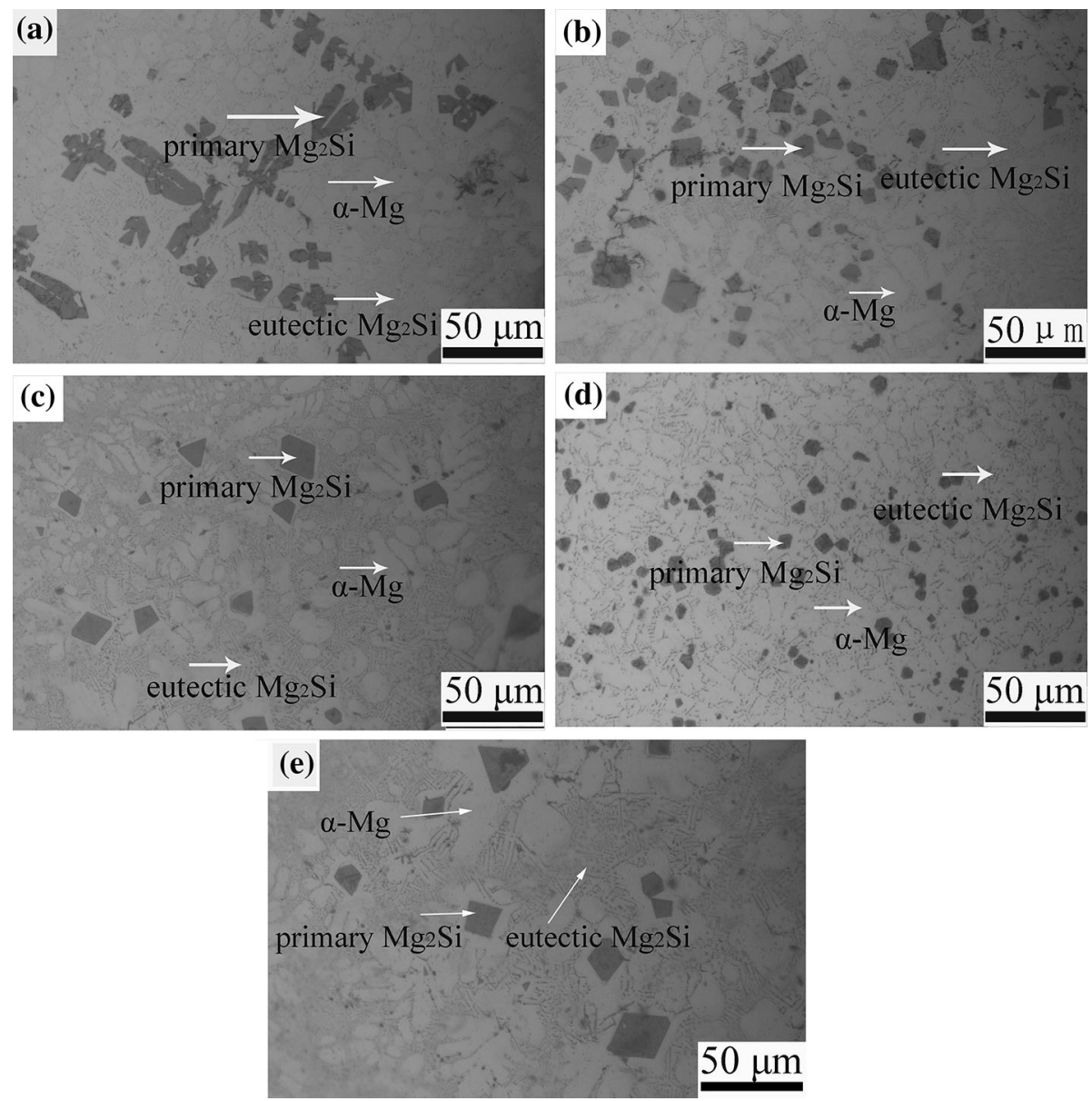

Fig. 2 Microstructures of Mg-4Si alloy (a) without modification and with modification of (b) $1.0 \mathrm{Sb}$, (c) $1.0 \mathrm{Sb}-0.5 \mathrm{Nd}$, (d) $1.0 \mathrm{Sb}-1.0 \mathrm{Nd}$, and (e) $1.0 \mathrm{Sb}-2.0 \mathrm{Nd}(\mathrm{wt} . \%)$

reduced. To better modify the refined primary $\mathrm{Mg}_{2} \mathrm{Si}$ particles, increasing ratios of $\mathrm{Nd}$ were added to the $1.0 \mathrm{wt} . \% \mathrm{Sb}$ metamorphic $\mathrm{Mg}-4 \mathrm{Si}$ alloy. The addition of $\mathrm{Nd}$ makes the average particle size decrease significantly, and the particle size of primary $\mathrm{Mg}_{2} \mathrm{Si}$ increases slightly when the addition amount of $\mathrm{Nd}$ is up to $1.0 \mathrm{wt} . \%$.

Figure 2(c) shows that after adding $1.0 \mathrm{wt} \% \mathrm{Sb}$ and 0.5 wt. $\% \mathrm{Nd}$, the number of primary $\mathrm{Mg}_{2} \mathrm{Si}$ particles decreased with increasing eutectic $\mathrm{Mg}_{2} \mathrm{Si}$ content, and the particle size changed slightly. Figure 2(d) shows that with the increase in $\mathrm{Nd}$ content, the average size of primary $\mathrm{Mg}_{2} \mathrm{Si}$ particles decreased significantly upon addition of $1.0 \mathrm{wt} \% \mathrm{Nd}$. The $\mathrm{Mg}_{2} \mathrm{Si}$ particles have the best polygon, and the average particle size obtained by $\mathrm{OM}$ is $6.5 \mu \mathrm{m}$. However, the amount of primary $\mathrm{Mg}_{2} \mathrm{Si}$ particles decreased, and the size became larger when the $\mathrm{Nd}$ was continuously added to the alloy (Fig. 2e). At the same time, the changes in the average size and density of the primary $\mathrm{Mg}_{2} \mathrm{Si}$ particles are plotted in Fig. 3; the density of the primary $\mathrm{Mg}_{2} \mathrm{Si}$ particles increased with decreasing size. Figure 4 shows the magnified SEM observation on the alloys with different $\mathrm{Sb}$ and $\mathrm{Nd}$ addition, indicating that the Chinesescript eutectic $\mathrm{Mg}_{2} \mathrm{Si}$ was significantly refined after the compound modification of $\mathrm{Sb}$ and $\mathrm{Nd}$, and the amount of the eutectic $\mathrm{Mg}_{2} \mathrm{Si}$ reduced with the addition of $\mathrm{Nd}$ up to $1.0 \mathrm{wt} . \%$.

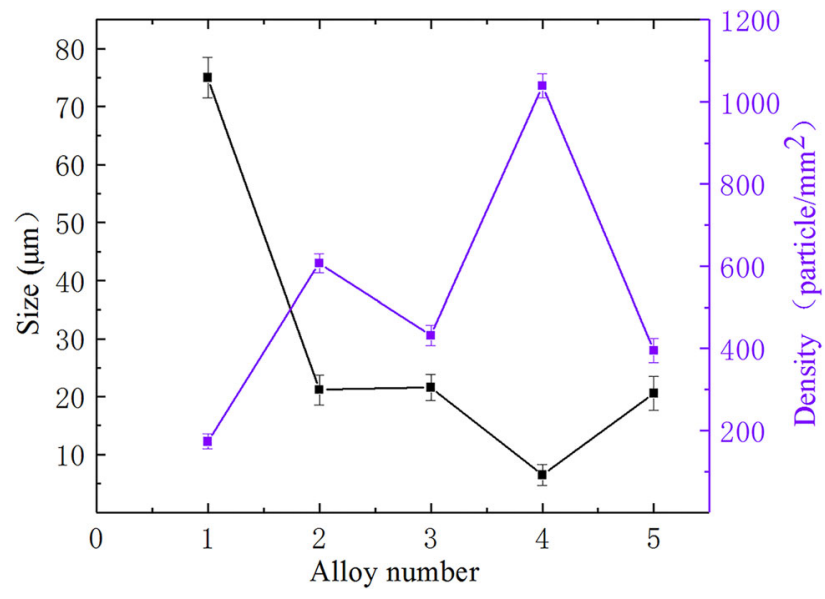

Fig. 3 Average size of primary $\mathrm{Mg}_{2} \mathrm{Si}$ particles

\subsection{Modification Mechanism}

The results show that the addition of $1.0 \mathrm{wt} \% \mathrm{Sb}$ and 1.0 wt. $\% \mathrm{Nd}$ has obvious compound modification effect on the primary $\mathrm{Mg}_{2} \mathrm{Si}$ phase of $\mathrm{Mg}-4 \mathrm{Si}$ alloy. The modification mechanism of $\mathrm{Nd}$ and $\mathrm{Sb}$ on $\mathrm{Mg}-4 \mathrm{Si}$ alloy was studied by 


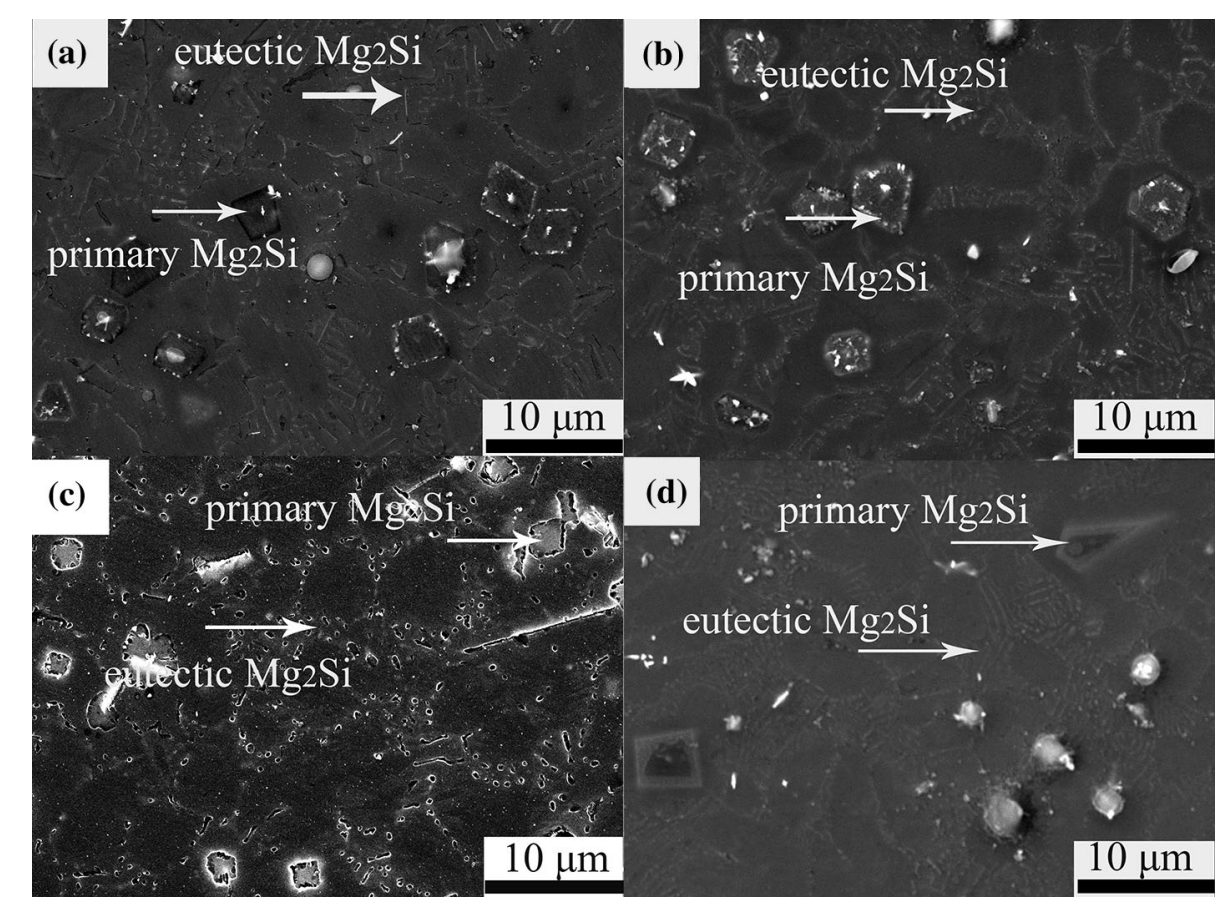

Fig. 4 Secondary electron SEM image of Mg-4Si alloy with chemical etched, (a) alloy 2, (b) alloy 3, (c) alloy 4, (d) alloy 5

(a)
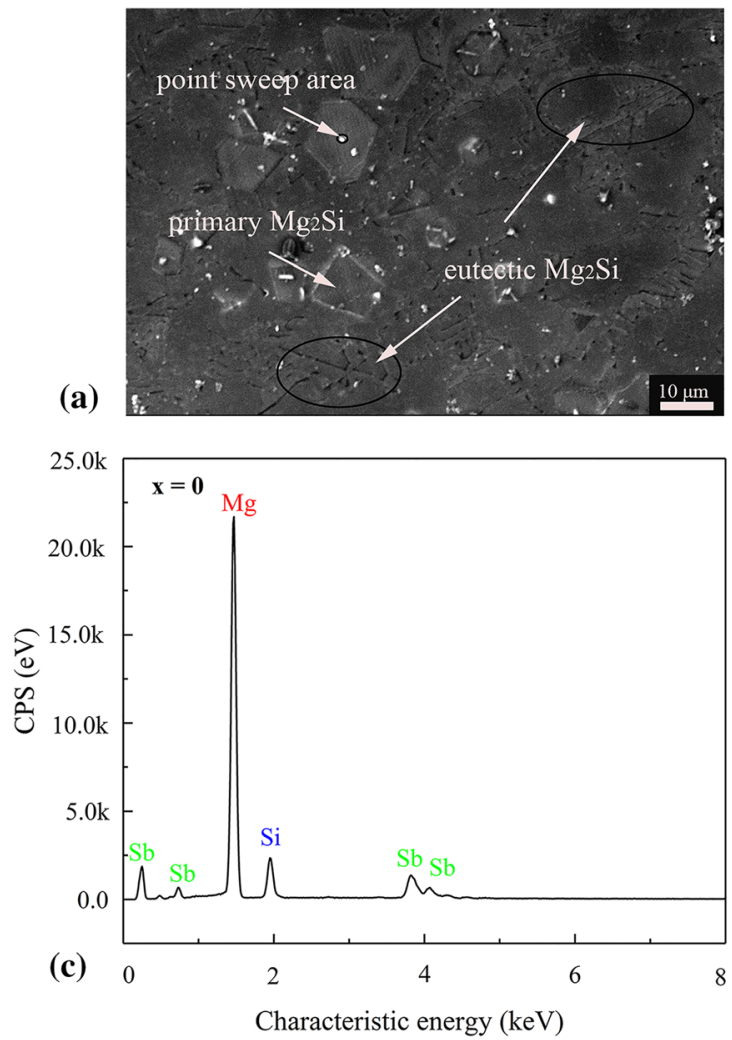

(b)
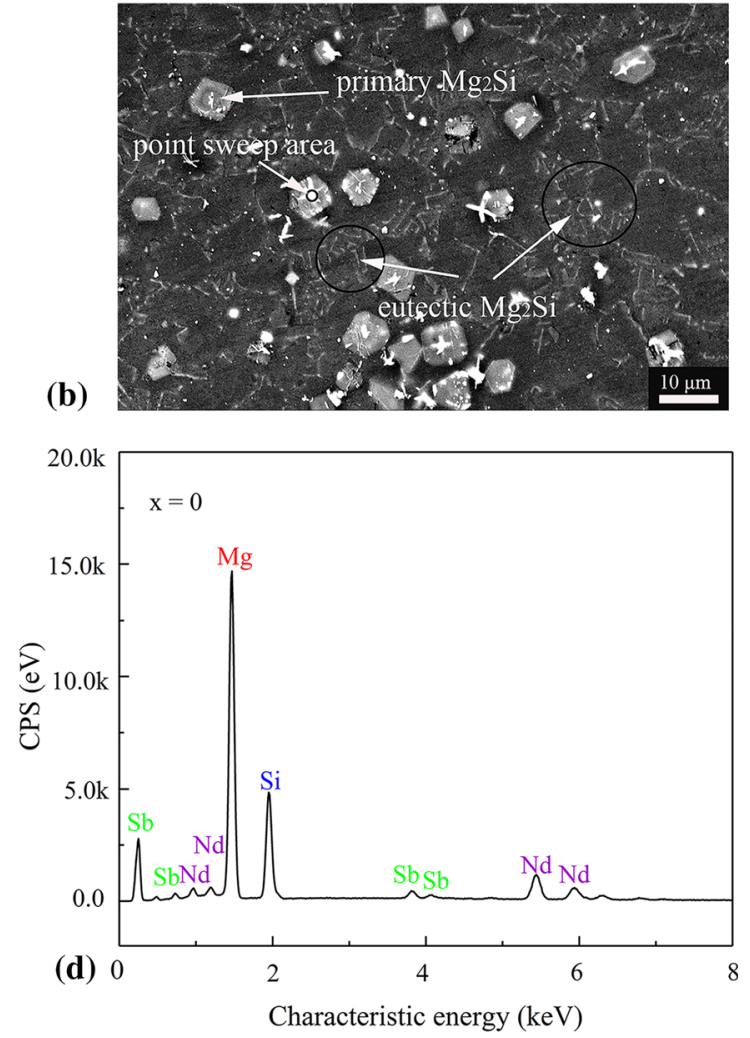

Fig. 5 (a) Secondary electron SEM image of Mg-4Si alloy with chemical etched modified with 1 wt.\% Sb and (c) point EDS analysis; (b) SEM image of Mg-4Si alloy modified with $1.0 \mathrm{wt} . \% \mathrm{Sb}$ and $1.0 \mathrm{wt} . \% \mathrm{Nd}$ and (d) point EDS analysis

SEM. There were white cores in the middle or edge of the modified $\mathrm{Mg}_{2} \mathrm{Si}$ phase (Fig. 5a and b), which could act as a heterogeneous nucleation core of the primary $\mathrm{Mg}_{2} \mathrm{Si}$ particles. Figure 5(a) and (c) shows the SEM images and EDS analysis of the 1 wt.\% Sb modified Mg-4Si alloy. Figure 5(a) shows that there are some white cores in the primary $\mathrm{Mg}_{2} \mathrm{Si}$ particles. There is a point sweep of the white cores in Fig. 5(a), which reveals that the constituent elements of the white cores are $\mathrm{Mg}$, $\mathrm{Si}$, and $\mathrm{Sb}$. Previous studies showed that the $\mathrm{Mg}_{3} \mathrm{Sb}_{2}$ phases can be formed in the $\mathrm{Mg}$-Si alloy after adding $\mathrm{Sb}$. These acted 
as nucleation sites for the primary $\mathrm{Mg}_{2} \mathrm{Si}$ particles (Ref 25). It can be seen from Fig. 5(a) that the $\mathrm{Mg}_{3} \mathrm{Sb}_{2}$ phase is too small, and the nucleation rate of the primary $\mathrm{Mg}_{2} \mathrm{Si}$ was minimally improved, so the average size of the primary $\mathrm{Mg}_{2} \mathrm{Si}$ particles was about $20 \mu \mathrm{m}$.

Figure 5(b) shows that the amount of white cores in the primary $\mathrm{Mg}_{2} \mathrm{Si}$ particles obviously increased after adding $1 \mathrm{wt} . \% \mathrm{Sb}$ and $1 \mathrm{wt} . \% \mathrm{Nd}$ to the $\mathrm{Mg}-4 \mathrm{Si}$ alloy. Meanwhile, the average size of primary $\mathrm{Mg}_{2} \mathrm{Si}$ particles decreased to $6.5 \mu \mathrm{m}$ and was evenly distributed in the matrix; eutectic $\mathrm{Mg}_{2} \mathrm{Si}$ changed from Chinese characters to small short fibers. The point sweep of the white core in the primary $\mathrm{Mg}_{2} \mathrm{Si}$ particles in Fig. 5(d) reveals that there are $\mathrm{Mg}, \mathrm{Si}, \mathrm{Sb}$, and $\mathrm{Nd}$ on the white cores - the possible intermetallic compounds between these elements include $\mathrm{Mg}_{3} \mathrm{Sb}_{2}, \mathrm{NdSi}_{2}$, and $\mathrm{Nd}_{4} \mathrm{Sb}_{3}$.

The element composition of the core of the primary $\mathrm{Mg}_{2} \mathrm{Si}$ particles will be confirmed in a future TEM study. Figure 6 shows a high-power bright TEM image with mapping analysis. The bright image (Fig. 6a) shows a dark phase that we think is the $\alpha-\mathrm{Mg}$ phase, and there is also a white phase inside the $\mathrm{Mg}_{2} \mathrm{Si}$ particles that is heterogeneous nucleation core of the primary $\mathrm{Mg}_{2} \mathrm{Si}$ particles. The mapping analysis shows that there are $\mathrm{Nd}$ and $\mathrm{Sb}$ enrichments in the white core of the primary $\mathrm{Mg}_{2} \mathrm{Si}$ particles (Fig. 6e and f). The white intermediate phase is likely a compound of Nd and Sb (Ref 26).

Figure 7 shows the high-power bright-field TEM image and selected area electron diffraction image of $\mathrm{Mg}-4 \mathrm{Si}$ alloy with 1.0 wt. $\% \mathrm{Sb}$ and 1.0 wt.\% alloyed Nd. The SAD pattern was collected from at least two regional axes by tilting the sample to determine the crystal structure (Ref 27). The target and selected area electron diffraction aperture were adjusted, and the intermetallics of $\mathrm{Nd}$ and $\mathrm{Sb}$ nanoparticles were studied. The area circled by the solid circle of $100 \mathrm{~nm}$ is the area of the selected area electron diffraction analysis. The SAD patterns were analyzed, and the results suggest that the core of the primary $\mathrm{Mg}_{2} \mathrm{Si}$ consists of a $\mathrm{Nd}_{4} \mathrm{Sb}_{3}$ phase and a zone axis $A=[1 \overline{3} 1]$. Through these, the $\mathrm{Nd}_{4} \mathrm{Sb}_{3}$ phase has a cubic structure with lattice parameters of $0.9406 \mathrm{~nm}$ and belongs to
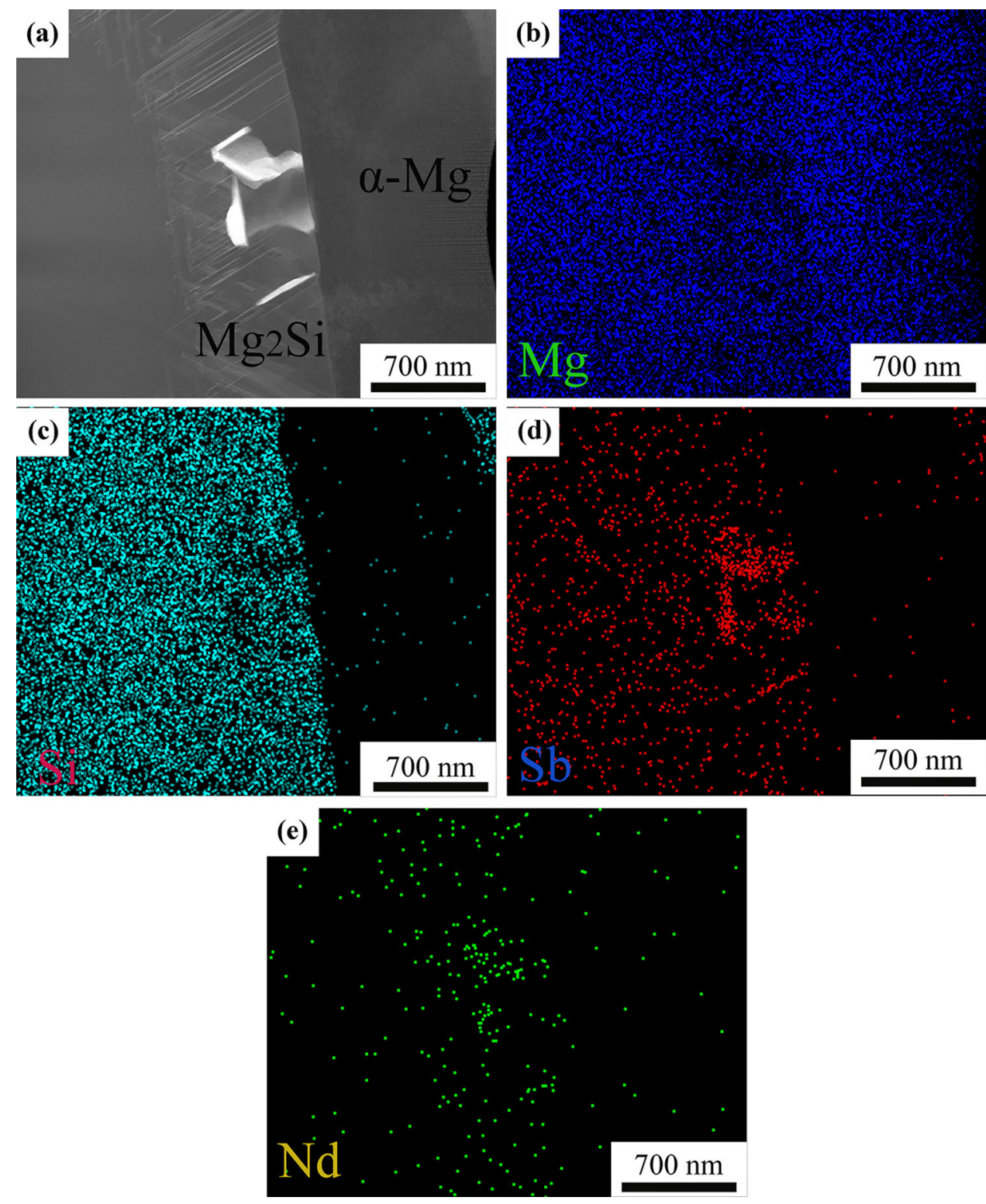

Fig. 6 (a) TEM bright image; EDS elemental mappings of (b) $\mathrm{Mg}$; (c) Si; (d) Sb; and (e) Nd 

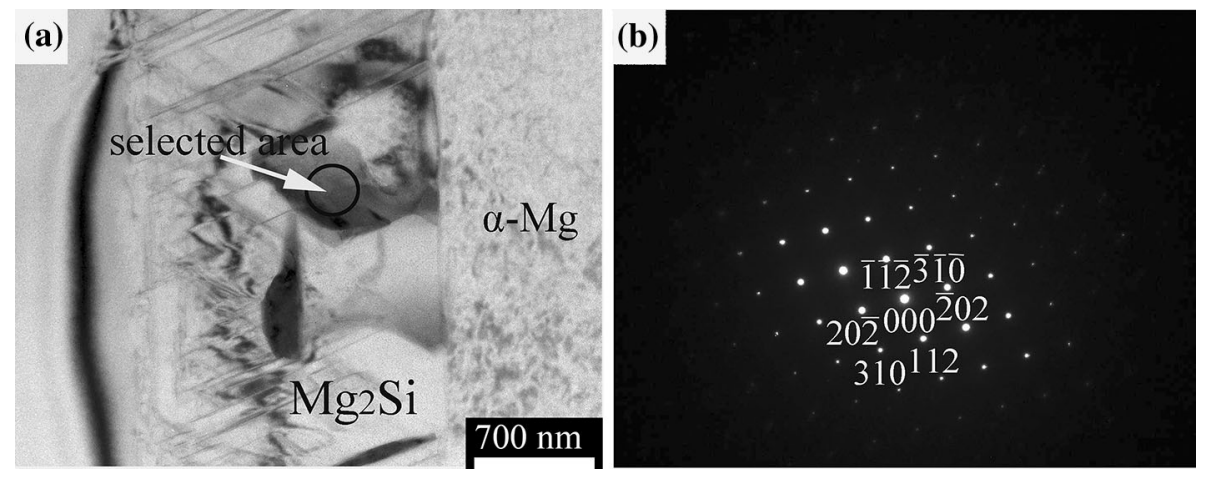

Fig. 7 (a) TEM bright image; (b) TEM SAD pattern taken from area circle

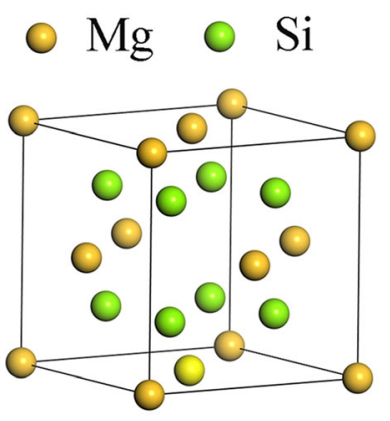

$\mathrm{Mg}_{2} \mathrm{Si}$
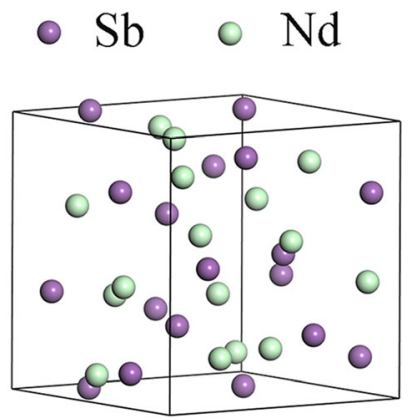

$\mathrm{Nd}_{4} \mathrm{Sb}_{3}$

Fig. 8 Crystal structures of $\mathrm{Mg}_{2} \mathrm{Si}$ and $\mathrm{Nd}_{4} \mathrm{Sb}_{3}$

the I-43d (220) space group. In addition, the $\mathrm{Mg}_{2} \mathrm{Si}$ phase has a face-centered cubic structure with lattice parameters of $0.65 \mathrm{~nm}$ (Ref 28). This belongs to the Fm-3m (225) space group. Figure 8 shows the crystal structure of the $\mathrm{Mg}_{2} \mathrm{Si}$ phase and the $\mathrm{Nd}_{4} \mathrm{Sb}_{3}$ phase, respectively.

In previous studies, the modification and refinement mechanism of different elements in $\mathrm{Mg}-4 \mathrm{Si}$ alloy was discussed. Adding alloying elements and appropriate modifiers can effectively change the morphology of $\mathrm{Mg}_{2} \mathrm{Si}$ particles. This method is simple and efficient. The modification mechanism of the addition of $\mathrm{Sb}$ or $\mathrm{Nd}$ is to form a kind of heterogeneous nucleation core of $\mathrm{Mg}_{2} \mathrm{Si}$ particles, and it will increase the nucleation rate (Ref 11,14 ). For example, the $\mathrm{Mg}_{3} \mathrm{Sb}_{2}$ phase will be formed, while $\mathrm{Sb}$ was added to the $\mathrm{Mg}$-Si alloys (Ref 12). These are the nucleation centers of primary $\mathrm{Mg}_{2} \mathrm{Si}$ particles. When $\mathrm{Nd}$ is added to the alloy, $\mathrm{NdSi}_{2}$ can play a similar role to the $\mathrm{Mg}_{2} \mathrm{Si}$ particles (Ref 14). However, when $\mathrm{Sb}$ and $\mathrm{Nd}$ were added at the same time, no $\mathrm{Mg}_{3} \mathrm{Sb}_{2}$ or $\mathrm{NdSi}_{2}$ particles were observed. In contrast, only $\mathrm{Nd}_{4} \mathrm{Sb}_{3}$ particles were detected in the newly formed phase; no other intermediate phase was observed. This can be explained by the differences in electronegativity of different atoms.

Electronegativity is a measure of an atom's ability to attract electrons. A higher electronegativity implies a stronger ability to attract electrons. In general, larger electronegativity differences lead to higher attraction and greater potential for compound formation. The electronegativity of $\mathrm{Nd}, \mathrm{Sb}, \mathrm{Mg}$, and $\mathrm{Si}$ is $1.14,2.05,1.31$, and 1.98, respectively. Obviously, the electronegativity difference between $\mathrm{Nd}$ and $\mathrm{Sb}$ is much larger than the electronegativity difference between $\mathrm{Mg}$ and $\mathrm{Sb}$, or $\mathrm{Nd}$ and $\mathrm{Si}$. Therefore, $\mathrm{Nd}$ and $\mathrm{Sb}$ combine to form $\mathrm{Nd}_{4} \mathrm{Sb}_{3}$ phases

instead of $\mathrm{Mg}_{3} \mathrm{Sb}_{2}$ phases and $\mathrm{NdSi}_{2}$ phases as other studies have done.

In order to investigate whether the $\mathrm{Nd}_{4} \mathrm{Sb}_{3}$ phase can be used as the heterogeneous nucleation core of the $\mathrm{Mg}_{2} \mathrm{Si}$ phase, the lattice mismatch between $\mathrm{Nd}_{4} \mathrm{Sb}_{3}$ and $\mathrm{Mg}_{2} \mathrm{Si}$ was calculated according to Bramfitt theory. The Bramfitt theoretical calculation formula is shown as follows ( $\operatorname{Ref} 25)$ :

$\delta_{(h k l) n}^{(h k l) s}=\frac{1}{3} \sum_{i=1}^{3} \frac{\left|d[u v w]_{s}^{i} \cos \theta-d[u v w]_{n}^{i}\right|}{3 d_{[u v w]_{n}}^{i}}$

Here, $(h k l)_{s}$ is the low-index crystal plane of the heterogeneous substrate, and $[u v w]_{S}$ is the low-index crystal orientation in the $(h k l)_{s}$ plane. Term $(h k l)_{n}$ is the low-index crystal plane of the new crystal nucleus, and $[u v w]_{n}$ is the low-index crystal orientation in the $(h k l)_{n}$ plane. Terms $d_{[u v w] s}$ and $d_{[u v w] n}$ are atomic spatial distances along the $[u v w]_{s}$ and $[u v w]_{n}$ orientations, and $\theta$ is the angle between $[u v w]_{s}$ and $[u v w]_{n}$ orientations $\left(\theta<90^{\circ}\right)$.

Through the study of Bramfitt theory, the energy at the boundary of the heterogeneous nucleation core and the $\mathrm{Mg}_{2} \mathrm{Si}$ phase affects the formation of the heterogeneous core. This is mainly related to the energy at the contact surface, and the key to the formation of the heterogeneous nucleation core is that the lattice mismatch of the contact surface is less than $15 \%$.

Figure 9 shows the (001) crystal plane of the $\mathrm{Mg}_{2} \mathrm{Si}$ phase and the (211) crystal plane of the $\mathrm{Nd}_{4} \mathrm{Sb}_{3}$ phase. The planar mismatch of some possible crystallographic orientations for $\mathrm{Mg}_{2} \mathrm{Si}$ nucleation on the $\mathrm{Nd}_{4} \mathrm{Sb}_{3}$ particles was calculated according to Fig. 9 and Bramfitt theory. Table 2 shows that the disregistry reaches $9.33 \%$ when the orientation relationship between $\mathrm{Nd}_{4} \mathrm{Sb}_{3}$ and $\mathrm{Mg}_{2} \mathrm{Si}$ is $(211)_{\mathrm{Nd} 4 \mathrm{Sb} 3} \|(001)_{\mathrm{Mg} 2 \mathrm{Si}}$. From Bramfitt's theory, the mismatch between two-phase planes is less than $15 \%$, and one phase can act as a heterogeneous nucleation point for the other phase. Therefore, the $\mathrm{Nd}_{4} \mathrm{Sb}_{3}$ phase can be used as a heterogeneous nucleus of primary $\mathrm{Mg}_{2} \mathrm{Si}$ phase. The formation of a large number of fine $\mathrm{Nd}_{4} \mathrm{Sb}_{3}$ particles improved the nucleation rate of primary $\mathrm{Mg}_{2} \mathrm{Si}$ particles. Therefore, during solidification, the core of the primary $\mathrm{Mg}_{2} \mathrm{Si}$ increases and is evenly distributed in the matrix. The primary $\mathrm{Mg}_{2} \mathrm{Si}$ particles do not grow into dendritic crystals, but rather become a small regular polygon.

The results show that the average size of the primary $\mathrm{Mg}_{2} \mathrm{Si}$ particles is much smaller than that of the single $\mathrm{Nd}$ or $\mathrm{Sb}$ element after adding $\mathrm{Nd}$ and $\mathrm{Sb}$ at the same time. This is due to that adding 1.0 wt.\% $\mathrm{Nd}$ and $1.0 \mathrm{wt} . \% \mathrm{Sb}$ to $\mathrm{Mg}-4 \mathrm{Si}$ alloy can form a $\mathrm{Nd}_{4} \mathrm{Sb}_{3}$ phase, which is the heterogeneous nucleation 


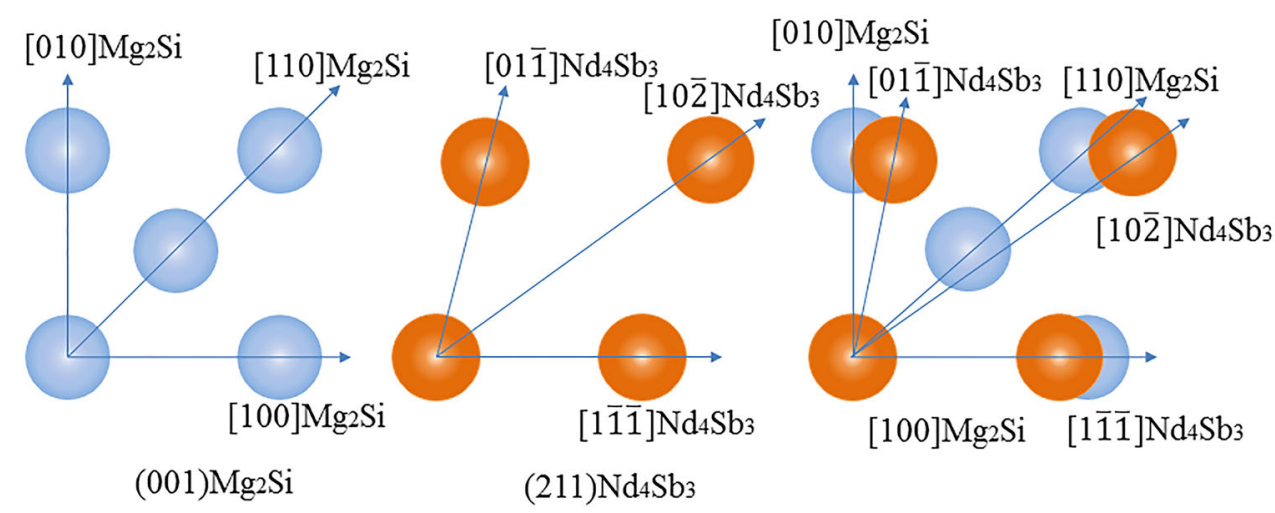

Fig. 9 Comparison of atomic arrangements in (001) $\mathrm{Mg}_{2} \mathrm{Si}$ and (211) $\mathrm{Nd}_{4} \mathrm{Sb}_{3}$

Table 2 Calculated values for planar disregistry between $\mathrm{Mg}_{2} \mathrm{Si}$ and $\mathrm{Nd}_{4} \mathrm{Sb}_{3}$

\begin{tabular}{|c|c|c|c|c|c|c|c|c|c|}
\hline \multirow[b]{2}{*}{$(h k l) \mathrm{Nd}_{4} \mathrm{Sb}_{3}$} & \multicolumn{3}{|c|}{$(\mathbf{0 0 1}) \mathbf{N d}_{4} \mathbf{S b}_{3} \|(001) \mathbf{M g}_{2} \mathbf{S i}$} & \multicolumn{3}{|c|}{$(110) \mathbf{N d}_{4} \mathbf{S b} \|(001) \mathbf{M g}_{2} \mathbf{S i}$} & \multicolumn{3}{|c|}{$(\mathbf{2 1 1}) \mathbf{N d}_{\mathbf{4}} \mathbf{S b}_{3} \|(001) \mathrm{Mg}_{2} \mathbf{S i}$} \\
\hline & [010] & {$[320]$} & {$[120]$} & {$[\overline{1} 00]$} & {$[\overline{2} 10]$} & {$[\overline{3} 20]$} & {$[1 \overline{11}]$} & {$[10 \overline{2}]$} & 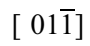 \\
\hline$(h k 1) \mathrm{Mg}_{2} \mathrm{Si}$ & {$[100]$} & {$[110]$} & {$[010]$} & {$[100]$} & {$[110]$} & {$[010]$} & {$[100]$} & {$[110]$} & {$[010]$} \\
\hline$d(h k l) \mathrm{Nd}_{4} \mathrm{Sb}_{3}$ & 9.40 & 2.59 & 4.19 & 9.40 & 4.19 & 2.59 & 5.41 & 6.35 & 6.42 \\
\hline$d(h k l) \mathrm{Mg}_{2} \mathrm{Si}$ & 6.35 & 4.49 & 6.35 & 6.35 & 4.49 & 6.35 & 6.35 & 4.49 & 6.35 \\
\hline$\theta$ deg & 0 & 12 & 0 & 0 & 15 & 0 & 0 & 15 & 10 \\
\hline$\delta$ & & 46.15 & & & 40.23 & & & 9.33 & \\
\hline
\end{tabular}

center of primary $\mathrm{Mg}_{2} \mathrm{Si}$ particles. Therefore, the nucleation rate of the primary $\mathrm{Mg}_{2} \mathrm{Si}$ phase is greatly increased, and the morphology of $\mathrm{Mg}_{2} \mathrm{Si}$ changes from a coarse dendritic shape to a regular polygon. However, as the $\mathrm{Nd}$ content exceeds 1.0 wt. $\%$, the primary $\mathrm{Mg}_{2} \mathrm{Si}$ particles begin to grow slightly larger. This is because of the Nd-Sb binary phase diagram. The $\mathrm{Nd}_{4} \mathrm{Sb}_{3}$ phase can be formed when the contents of $\mathrm{Nd}$ and $\mathrm{Sb}$ are close to each other. With increasing addition of $\mathrm{Nd}$, the $\mathrm{Nd}_{5} \mathrm{Sb}_{3}$ phase can finally be formed, but it cannot act as a heterogeneous nucleation site for the primary $\mathrm{Mg}_{2} \mathrm{Si}$ particles. Therefore, the nucleation rate of primary $\mathrm{Mg}_{2} \mathrm{Si}$ decreases and the primary $\mathrm{Mg}_{2} \mathrm{Si}$ particles become much larger. Meanwhile, the amount of Chinese eutectic $\mathrm{Mg}_{2} \mathrm{Si}$ increases sharply with much more alloyed Nd. This is called the over-modification phenomenon.

\subsection{Mechanical Properties}

The tensile mechanical properties and hardness of different samples were tested to investigate the effect of adding different amounts of modifier on the mechanical properties of $\mathrm{Mg}-4 \mathrm{Si}$ alloy (Fig. 10 and 11).

3.4.1 Hardness. The change of hardness can be found in Fig. 10 of Mg-4Si alloy after adding different amounts of $\mathrm{Nd}$ and Sb. Figure 10 shows that the Brinell hardness of the unmodified Mg-4Si alloy is at least HB 65.45, and the Brinell hardness value of the alloy first increases and then decreases upon addition of different amounts of modifiers. The maximum value was $\mathrm{HB} 89.17$, and this was achieved upon modification of $1.0 \mathrm{wt} . \% \mathrm{Sb}$ and $1.0 \mathrm{wt} . \% \mathrm{Nd}$. These results indicate that the hardness value of the $\mathrm{Mg}-4 \mathrm{Si}$ alloy is related to the morphology of the primary $\mathrm{Mg}_{2} \mathrm{Si}$ particles. The fine regular polygonal

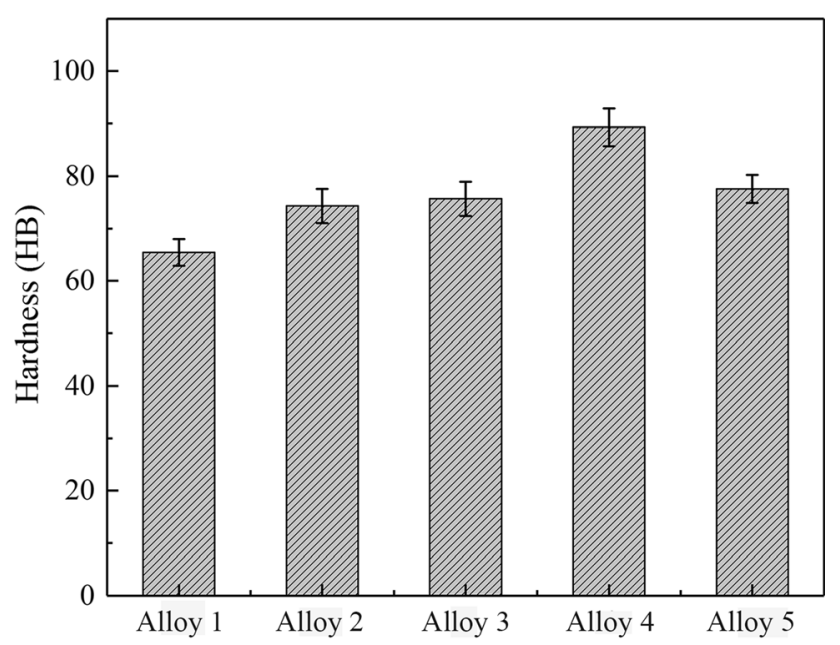

Fig. 10 Effect of different contents of $\mathrm{Sb}$ and $\mathrm{Nd}$ on the Brinell hardness of Mg-4Si alloy

particles contribute to the improvement of the hardness. This is because the stress at the contact point of the $\mathrm{Mg}_{2} \mathrm{Si}$ particles with the magnesium matrix is reduced after deformation. Thus, it is difficult to initiate cracks at the interface between the primary $\mathrm{Mg}_{2} \mathrm{Si}$ particles and magnesium matrix. Thus, the hardness of the alloy increased via $1.0 \mathrm{wt} . \% \mathrm{Sb}$ and $1.0 \mathrm{wt} . \%$ $\mathrm{Nd}$ modification.

3.4.2 Tensile Properties and Fracture Characteristics. Tensile properties of $\mathrm{Mg}-4 \mathrm{Si}$ alloy modified by different content $\mathrm{Sb}$ and $\mathrm{Nd}$ are shown in Fig. 11. The ultimate tensile strength in the experiment is raised from 113.24 to $175.38 \mathrm{MPa}$ 
when the Mg-4Si alloy was modified by adding 1.0 wt. $\% \mathrm{Nd}$ and 1.0 wt. $\% \mathrm{Sb}$. With the elongation increases from $2.23 \%$ to $4.61 \%$, it is clear that improvement of the mechanical properties of the alloy is closely related to the morphology of the $\mathrm{Mg}_{2} \mathrm{Si}$ reinforced phase. This is because of the thermal expansion coefficient between the matrix and the reinforcing phase and

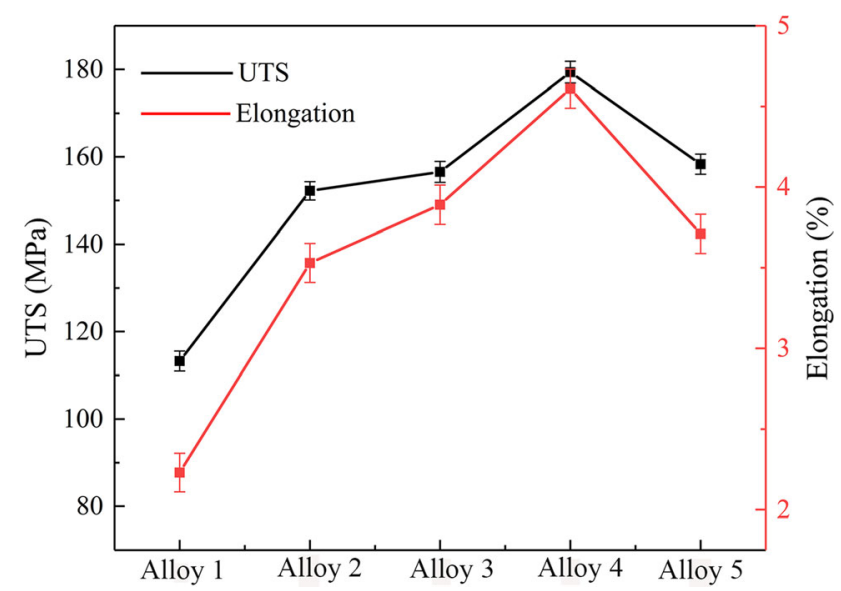

Fig. 11 Effect of different contents of $\mathrm{Sb}$ and $\mathrm{Nd}$ on the tensile properties of $\mathrm{Mg}-4 \mathrm{Si}$ alloy the Griffith formula.

An improved coefficient of thermal expansion (CTE) mismatch can increase the ultimate tensile strength of the Mg-4Si alloy (Ref 29). Due to the large difference in the CTE between $\alpha-\mathrm{Mg}$ and $\mathrm{Mg}_{2} \mathrm{Si}$ reinforcement phase, there is a relatively large residual stress between $\mathrm{Mg}_{2} \mathrm{Si}$ and magnesium matrix during alloy smelting. Residual stress concentration at the grain boundary produces many high-density dislocations between the magnesium matrix and the $\mathrm{Mg}_{2} \mathrm{Si}$ reinforcing phase, and the dislocation motion of the material becomes more difficult resulting in an increase in the strength of the material. The CTE mismatch is related to the size and shape of the reinforcing phase particles( $\operatorname{Ref} 30$ ). The eutectic $\mathrm{Mg}_{2} \mathrm{Si}$ was still refined after adding $1.0 \mathrm{wt} . \% \mathrm{Sb}$ and $1.0 \mathrm{wt} . \% \mathrm{Nd}$ to the $\mathrm{Mg}-4 \mathrm{Si}$ alloy; thus, the alloys were further strengthened with the addition of $\mathrm{Nd}$ up to $1.0 \mathrm{wt} . \%$.

The other strengthening mechanism is related to the size of the primary $\mathrm{Mg}_{2} \mathrm{Si}$ particles; the relationship between the particle diameter $(d)$ and the fracture stress $\left(\sigma_{c}\right)$ was demonstrated by the Griffith equation as follows (Ref 12):

$\sigma_{c}=k_{c} d^{-0.5}$

Here, $k_{c}$ is the fracture toughness of the particle, and $d$ is the diameter of the particle. Griffith's theory states that the fracture stress of the test alloy increases with decreased particle diameter. The primary $\mathrm{Mg}_{2} \mathrm{Si}$ particle size decreases signifi-

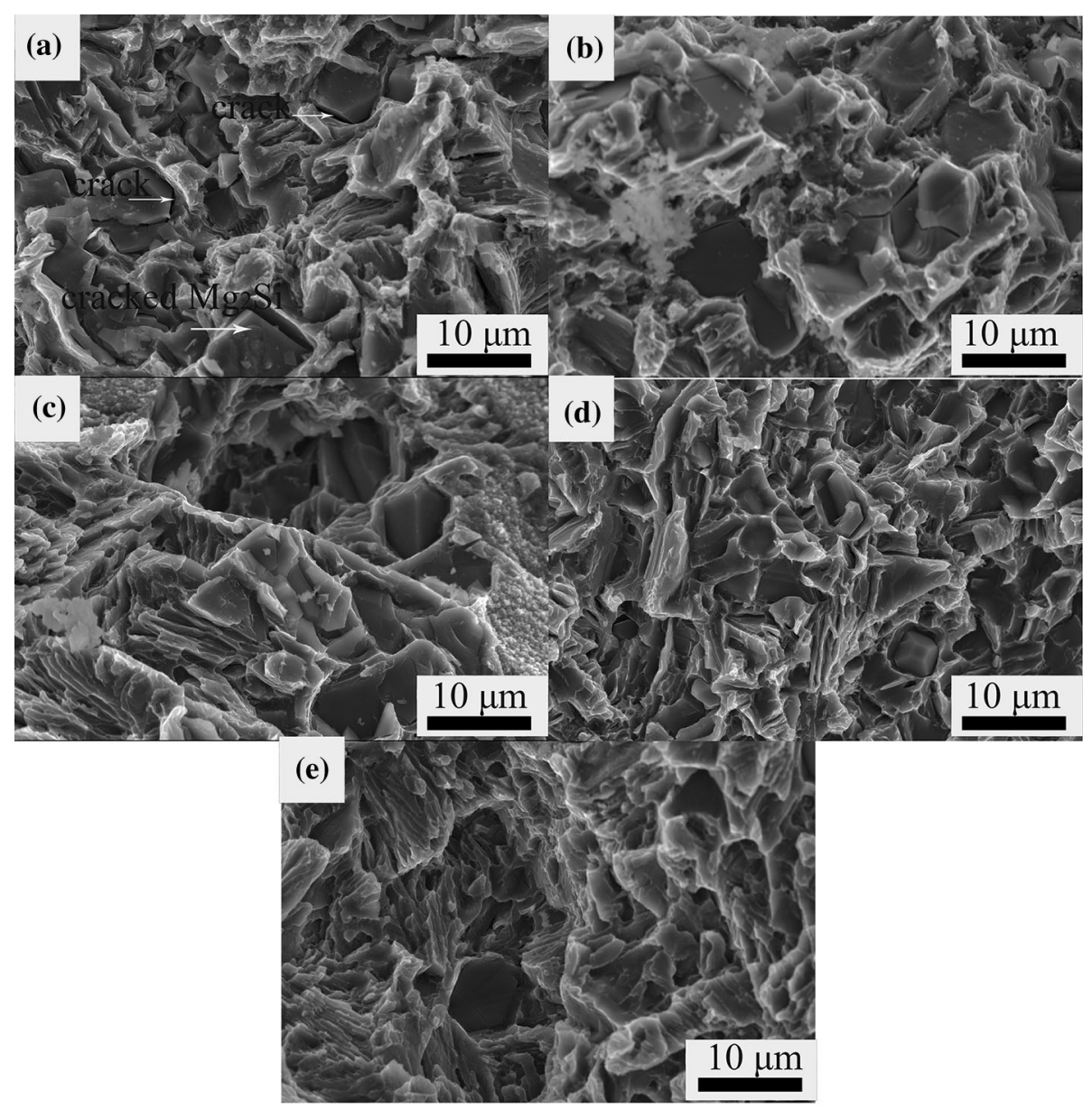

Fig. 12 Representative micrograph of a fractured surface on the Mg-4Si alloy: (a) alloy 1; (b) alloy 2; (c) alloy 3; (d) alloy 4; (e) alloy 5 
cantly in the Mg-4Si alloy with the addition of $1.0 \mathrm{wt} . \% \mathrm{Nd}$ and $1.0 \mathrm{wt} . \% \mathrm{Sb}$. This means that more stress is needed to break the Mg-4Si alloy after $1.0 \% \mathrm{Nd}$ and $1.0 \% \mathrm{Sb}$ addition. This improves the UTS and elongation values.

The typical fracture surface of the test alloy after adding different amounts of $\mathrm{Nd}$ and $\mathrm{Sb}$ to the alloys is shown in Fig. 12. Figure 12(a) shows that the cross section of the unmodified Mg-4Si alloy consists of a flat tearing surface on the $\mathrm{Mg}_{2} \mathrm{Si}$ particles. These tearing surfaces are irregularly shaped with cracks. This is attributed to the presence of coarse dendritic primary $\mathrm{Mg}_{2} \mathrm{Si}$ and Chinese eutectic $\mathrm{Mg}_{2} \mathrm{Si}$ in the unmodified $\mathrm{Mg}$-4Si alloy. The sharp edges of the unmodified primary $\mathrm{Mg}_{2} \mathrm{Si}$ particles generate a large amount of stress when they are in contact with the magnesium matrix, and these particles are concentrated at the grain boundaries. The crack is generated under a tensile load, and this crack expanded along the edge of the unmodified primary $\mathrm{Mg}_{2} \mathrm{Si}$ and eutectic $\mathrm{Mg}_{2} \mathrm{Si}$, which will reduce the strength and elongation of the alloy.

Figure 12(b-e) shows the fracture surface of the alloy with different $\mathrm{Nd}$ and $\mathrm{Sb}$ addition. It can be seen that the smaller the particles falling off, the less obvious the crack growth is. The $\mathrm{Mg}_{2} \mathrm{Si}$ phase prefers to act as the potential crack initiation site, so the refined $\mathrm{Mg}_{2} \mathrm{Si}$ phases could decrease the stress concentration and prevent the crack initiation (Ref 31, 32). This indicated that the ultimate tensile strength improved due to that the morphology of primary $\mathrm{Mg}_{2} \mathrm{Si}$ was changed from coarse dendrite to regular polygon by the addition of $\mathrm{Sb}$ and $\mathrm{Nd}$. Meanwhile, the morphology of eutectic $\mathrm{Mg}_{2} \mathrm{Si}$ was changed from Chinese character to small short rod. Small fine polygonal $\mathrm{Mg}_{2} \mathrm{Si}$ particles are benefitted to prevent the generation and development of cracks. Therefore, the ultimate tensile strength and elongation of the alloy have been greatly improved.

\section{Conclusions}

(1) The effect of the addition of Sb and Nd compound modification is as follows: The morphology of primary $\mathrm{Mg}_{2} \mathrm{Si}$ particles changes from coarse dendrite to regular shaped polygon, and the average size of the primary $\mathrm{Mg}_{2} \mathrm{Si}$ particles decreased to $6.5 \mu \mathrm{m}$ from $78 \mu \mathrm{m}$ after adding $1.0 \mathrm{wt} . \%$ of $\mathrm{Sb}$ and $1.0 \mathrm{wt} \% \mathrm{Nd}$. Furthermore, the amount of eutectic $\mathrm{Mg}_{2} \mathrm{Si}$ reduced with addition of $\mathrm{Nd}$ elements up to $1.0 \mathrm{wt} \%$. The Chinese-shaped eutectic $\mathrm{Mg}_{2} \mathrm{Si}$ is metamorphosed into a small short rod shape distributed in matrix. Therefore, the simultaneous addition of $\mathrm{Sb}$ and $\mathrm{Nd}$ is much better than the addition of $\mathrm{Sb}$ or $\mathrm{Nd}$ alone.

(2) The $\mathrm{Nd}_{4} \mathrm{Sb}_{3}$ phase appeared in the core of the primary $\mathrm{Mg}_{2} \mathrm{Si}$ particles after adding $1 \mathrm{wt} . \% \mathrm{Nd}$ and $1 \mathrm{wt} . \% \mathrm{Sb}$ to the $\mathrm{Mg}-4 \mathrm{Si}$ alloy. The crystal lattice mismatch between $\mathrm{Nd}_{4} \mathrm{Sb}_{3}$ and $\mathrm{Mg}_{2} \mathrm{Si}$ was $9.33 \%$ (less than $15 \%$ ), and thus, the $\mathrm{Nd}_{4} \mathrm{Sb}_{3}$ phase can be used as heterogeneous nucleation core of primary $\mathrm{Mg}_{2} \mathrm{Si}$ particles. Therefore, the nucleation rate of the $\mathrm{Mg}_{2} \mathrm{Si}$ phase is increased, and the primary $\mathrm{Mg}_{2} \mathrm{Si}$ particles become regular and uniformly distributed in the magnesium matrix.

(3) The hardness and tensile strength of the alloy increased with the modification of $\mathrm{Sb}$ and $\mathrm{Nd}$. The Brinell hardness of the alloy increased from HB 65.45 to HB 89.17. In addition, the mechanical properties showed that the UTS value increased from 113.24 to $175.38 \mathrm{MPa}$, and the elongation changes from 2.23 to $4.61 \%$. These are attributed to the compound modification for primary and eutectic $\mathrm{Mg}_{2} \mathrm{Si}$ particles.

\section{Acknowledgments}

We thank LetPub (www.letpub.com) for linguistic assistance during the preparation of this manuscript. This work was supported by the National Natural Science Foundation of China (Grant numbers 51975484 and 51605392).

\section{Funding}

This study was funded by 51975484 and 51605392 .

\section{Conflict of interest}

The authors declare that they have no conflict of interest.

\section{Open Access}

This article is licensed under a Creative Commons Attribution 4.0 International License, which permits use, sharing, adaptation, distribution and reproduction in any medium or format, as long as you give appropriate credit to the original author(s) and the source, provide a link to the Creative Commons licence, and indicate if changes were made. The images or other third party material in this article are included in the article's Creative Commons licence, unless indicated otherwise in a credit line to the material. If material is not included in the article's Creative Commons licence and your intended use is not permitted by statutory regulation or exceeds the permitted use, you will need to obtain permission directly from the copyright holder. To view a copy of this licence, visit http://creativecommons.org/licenses/by/4.0/.

\section{References}

1. W. Jiang, G. Li, Z. Fan, L. Wang, and F. Liu, Investigation on the Interface Characteristics of $\mathrm{Al} / \mathrm{Mg}$ Bimetallic Castings Processed by Lost Foam Casting, Metall. Mater. Trans. A, 2016, 47, p 2462-2470

2. Z. Jiang, Z. Fan, W. Jiang, G. Li, Y. Wu, F. Guan et al., Interfacial Microstructures and Mechanical Properties of Mg/Al Bimetal Produced by a Novel Liquid-Liquid Compound Casting Process, J. Mater. Process. Technol., 2018, 261, p 149-158

3. H.R. Bakhsheshi-Rad, E. Hamzah, S. Farahany, and M.P. Staiger, The Mechanical Properties and Corrosion Behavior of Quaternary Mg-6Zn0.8Mn-xCa Alloys, J. Mater. Eng. Perform., 2014, 24, p 598-608

4. Y. Chen, L. Wang, Y. Feng, E. Guo, S. Zhao, and L. Wang, Effect of Ca and $\mathrm{Sm}$ Combined Addition on the Microstructure and ElevatedTemperature Mechanical Properties of Mg-6Al Alloys, J. Mater. Eng. Perform., 2019, 28, p 2892-2902

5. M. Cong, Z. Li, J. Liu, M. Yan, K. Chen, Y. Sun et al., Effect of Ca on the Microstructure and Tensile Properties of $\mathrm{Mg}-\mathrm{Zn}-\mathrm{Si}$ Alloys at Ambient and Elevated Temperature, J. Alloys Compd., 2012, 539, p $168-173$

6. W. Jiang, Z. Fan, G. Li, L. Yang, and X. Liu, Effects of Melt-to-Solid Insert Volume Ratio on the Microstructures and Mechanical Properties of Al/Mg Bimetallic Castings Produced by Lost Foam Casting, Metall. Mater. Trans. A, 2016, 47, p 6487-6497

7. X. Qian, N. Parson, and X.G. Chen, Effect of Homogenization Treatment and Microalloying with Mn on the Microstructure and Hot Workability of AA6060 Aluminum Alloys, J. Mater. Eng. Perform., 2019, 28, p 4531-4542

8. T. Sakthivel, G. Sasikala, M.K. Dash, and P. Syamala Rao, Creep Deformation and Rupture Behavior of P92 Steel Weld Joint Fabricated 
by NG-TIG Welding Process, J. Mater. Eng. Perform., 2019, 28, p 4364-4378

9. P. Nieroda, A. Kolezynski, J. Leszczynski, J. Nieroda, and P. Pasierb, The Structural, Microstructural and Thermoelectric Properties of $\mathrm{Mg}_{2} \mathrm{Si}$ Synthesized by SPS Method Under Excess Mg Content Conditions, $J$. Alloys Compd., 2019, 775, p 138-149

10. C. Li, X. Liu, and Y. Wu, Refinement and Modification Performance of Al-P Master Alloy on Primary $\mathrm{Mg}_{2} \mathrm{Si}$ in Al-Mg-Si Alloys, J. Alloys Compd., 2008, 465, p 145-150

11. L. Liao, X. Zhang, H. Wang, X. Li, and N. Ma, Influence of Sb on Damping Capacity and Mechanical Properties of $\mathrm{Mg}_{2} \mathrm{Si} / \mathrm{Mg}-9 \mathrm{Al}$ Composite Materials, J. Alloys Compd., 2007, 430, p 292-296

12. H.Y. Wang, F. Liu, L. Chen, M. Zha, G.J. Liu, and Q.C. Jiang, The Effect of Sb Addition on Microstructures and Tensile Properties of Extruded Al-20Mg $\mathrm{Mg}_{2} \mathrm{Si}-4 \mathrm{Cu}$ Alloy, Mater. Sci. Eng. A, 2016, 657, p 331-338

13. K.K.A. Kumar, A. Viswanath, U.T.S. Pillai, B.C. Pai, and M. Chakraborty, Influence of Neodymium Addition on the Microstructure, Mechanical and Thermal Properties of Mg-Si Alloys, Proc. Eng., 2013, 55, p 103-108

14. H. J-1, C.-p. Tang, X.-m. Zhang, and Y.-1. Deng, Modification of $\mathrm{Mg}_{2} \mathrm{Si}$ in Mg-Si Alloys with Neodymium, Trans. Nonferr. Met. Soc., 2013, 23, p 3161-3166

15. K. Chen, Z.Q. Li, J.S. Liu, J.N. Yang, Y.D. Sun, and S.G. Bian, The Effect of Ba Addition on Microstructure of in Situ Synthesized $\mathrm{Mg}_{2} \mathrm{Si} /$ Mg-Zn-Si Composites, J. Alloys Compd., 2009, 487, p 293-297

16. J. Hou, C. Li, and X. Liu, Nucleating Role of an Effective in Situ $\mathrm{Mg}_{3} \mathrm{P}_{2}$ on $\mathrm{Mg}_{2} \mathrm{Si}$ in $\mathrm{Mg}-\mathrm{Al}-\mathrm{Si}$ Alloys, J. Alloys Compd., 2011, 509, $\mathrm{p}$ 735-739

17. Q.C. Jiang, H.Y. Wang, Y. Wang, B.X. Ma, and J.G. Wang, Modification of $\mathrm{Mg}_{2} \mathrm{Si}$ in $\mathrm{Mg}-\mathrm{Si}$ Alloys with Yttrium, Mater. Sci. Eng. A, 2005, 392, p 130-135

18. G. Mao, H. Yan, C. Zhu, Z. Wu, and W. Gao, The Varied Mechanisms of Yttrium (Y) Modifying a Hypoeutectic Al-Si Alloy Under Conditions of Different Cooling Rates, J. Alloys Compd., 2019, 806, p 909-916

19. M.-B. Yang, F.-S. Pan, J. Shen, and L. Bai, Comparison of $\mathrm{Sb}$ and $\mathrm{Sr}$ on Modification and Refinement of $\mathrm{Mg}_{2} \mathrm{Si}$ Phase in AZ61-0.7Si Magnesium Alloy, Trans. Nonferr. Met. Soc., 2009, 19, p 287-292

20. X.-F. Wu, Y. Wang, K.-Y. Wang, R.-D. Zhao, and F.-F. Wu, Enhanced Mechanical Properties of Hypoeutectic Al- $10 \mathrm{Mg}_{2} \mathrm{Si}$ Cast Alloys by $\mathrm{Bi}$ Addition, J. Alloys Compd., 2018, 767, p 163-172

21. K. Chen and Z. Li, Effect of Co-modification by $\mathrm{Ba}$ and $\mathrm{Sb}$ on the Microstructure of $\mathrm{Mg}_{2} \mathrm{Si} / \mathrm{Mg}-\mathrm{Zn}-\mathrm{Si}$ Composite and Mechanism, $J$. Alloys Compd., 2014, 592, p 196-201
22. D.H. Kang, G.T. Bae, and N.J. Kim, Effect of $\mathrm{Sb}$ and $\mathrm{Sr}$ Additions on the Microstructural Evolution of Mg-Sn-Al-Si Based Alloys, Mater. Trans., 2008, 49, p 936-940

23. H.-C. Yu, H.-Y. Wang, L. Chen, M. Zha, C. Wang, C. Li et al., Spheroidization of Primary $\mathrm{Mg}_{2} \mathrm{Si}$ in Al-20 $\mathrm{Mg}_{2} \mathrm{Si}-4.5 \mathrm{Cu}$ Alloy Modified with $\mathrm{Ca}$ and $\mathrm{Sb}$ During T6 Heat Treatment Process, Mater. Sci. Eng. A, 2017, 685, p 31-38

24. S. Farahany, H. Ghandvar, N.A. Nordin, A. Ourdjini, and M.H. Idris, Effect of Primary and Eutectic $\mathrm{Mg}_{2} \mathrm{Si}$ Crystal Modifications on the Mechanical Properties and Sliding Wear Behaviour of an Al-20Mg $2 \mathrm{Si}-$ 2Cu-xBi Composite, J. Mater. Sci. Technol., 2016, 32, p 1083-1097

25. Y. Wang and $X$. Guo, Heterogeneous Nucleation of $\mathrm{Mg}_{2} \mathrm{Si}$ and $\mathrm{Mg}_{2}(\mathrm{Si}$, $\mathrm{Sn})$ on $\mathrm{Mg}_{3} \mathrm{Sb}_{2}$ Nucleus in Mg Containing Si Alloys, Mater. Chem. Phys., 2019, 223, p 336-342

26. L. Sheng, L. Wang, T. Xi, Y. Zheng, and H. Ye, Microstructure, Precipitates and Compressive Properties of Various Holmium Doped $\mathrm{NiAl} / \mathrm{Cr}$ (Mo, Hf) Eutectic Alloys, Mater. Des., 2011, 32, p 4810-4817

27. H. Chang Shin, J. Son, B.K. Min, Y.S. Choi, K.M. Cho, D.H. Cho et al., The Effect of $\mathrm{Ce}$ on the Modification of $\mathrm{Mg}_{2} \mathrm{Si}$ Phases of As-Cast Eutectic Mg-Si Alloys, J. Alloys Compd., 2019, 792, p 59-68

28. A. Gil-Santos, I. Marco, N. Moelans, N. Hort, and O. Van der Biest, Microstructure and Degradation Performance of Biodegradable Mg-SiSr Implant Alloys, Mater. Sci. Eng. C Mater. Biol. Appl., 2017, 71, p 25-34

29. M. Wang, D. Chen, Z. Chen, Y. Wu, F. Wang, N. Ma et al., Mechanical Properties of in Situ $\mathrm{TiB}_{2} / \mathrm{A} 356$ Composites, Mater. Sci. Eng. A, 2014, 590, p 246-254

30. R. Du, D. Yuan, F. Li, D. Zhang, S. Wu, and S. Lü, Effect of in Situ $\mathrm{TiB}_{2}$ Particles on Microstructure and Mechanical Properties of $\mathrm{Mg}_{2} \mathrm{Si} /$ Al Composites, J. Alloys Compd., 2019, 776, p 536-542

31. B.N. Du, Z.P. Xiao, Y.X. Qiao, L. Zheng, B.Y. Yu, D.K. Xu et al., Optimization of Microstructure and Mechanical Property of a Mg-ZnY-Nd Alloy by Extrusion Process, J. Alloys Compd., 2019, 775, p 9901001

32. L.-Y. Sheng, F. Yang, T.-F. Xi, Y.-F. Zheng, and J.-T. Guo, Microstructure and Room Temperature Mechanical Properties of NiAl-Cr(Mo)-(Hf, Dy) Hypoeutectic Alloy Prepared by Injection Casting, Trans. Nonferr. Met. Soc., 2013, 23, p 983-990

Publisher's Note Springer Nature remains neutral with regard to jurisdictional claims in published maps and institutional affiliations. 